\title{
Heavy metal complexation by surfaces and humic acids: a brief discourse on assessment by acidimetric titration
}

\author{
Zi-jian Wang* and Werner Stumm \\ Institute of Aquatic Science (EAWAG), Swiss Federal Institute of Technology \\ (ETH), Zürich, Switzerland
}

Received 3 April 1987; accepted 4 June 1987

Key words: heavy metals, complexation, humic acids, iron (hydr)oxide, silica, voltammetry

\section{Summary}

In natural waters the form of occurrence of heavy metal ions needs to be known to understand the factors that control their concentrations, their reactivity and bioavailability. In natural samples one encounters difficulties in identifying the species present and in distinguishing between dissolved and particulate concentrations, because of the lack of sufficiently sensitive and specific analytical detectors. It is suggested that the voltammetric measurement of the labile metal ion concentration as a function of $\mathrm{pH}$ (from an acidimetric titration of a natural sample) may provide useful information on the $\mathrm{pH}$-dependent distribution of soluble and particulate concentrations and on the stability of (surface and solute) complexes formed.

\section{Introduction}

Our environment is controlled to a large extent by chemical cycles between the various systems of the earth, atmosphere, oceans, freshwater, biomass, rocks, soils, and sediments. In most of these reservoirs, the surface-to-volume ratios of the materials are large and thus many of the important processes are regulated by reactions at the interface. The weathering of rocks and the formation of soils are a consequence of surface reactions between minerals and water.

As has been pointed out by Bolt \& van Riemsdijk (1987), a large fraction of the water on its way from atmosphere to 'open water' is in contact with soil during a larger or shorter time period. During this contact period the interaction between water and the soil solid phases becomes the determining factor for changes in water quality.

\footnotetext{
* Visiting scholar from Institute of Environmental Chemistry, Academia Sinica Beijing. People's Republic of China.
} 
Soil systems consist of similar solvent (water), solute and solid components as natural water and sediment-water systems. Although there is a large difference in the relative quantity of the water present, the processes occurring at interfaces are, in principle, the same. Surface and colloid chemistry has become the common meeting ground for soil and water chemists. Thus, all aquatic chemists are indebted to Gerard Bolt and many of his colleagues, for the development of a conceptually sound basis of interfacial chemistry.

\section{Control of heavy metals}

The geochemistry of most trace elements is thought to be controlled by the reaction of solutes with solid surfaces. The solid water interface in soil and in natural water systems is characterized by inorganic colloids such as clays, metal (hydr)oxides and organic colloidal matter as well as biota. In order to understand the factors that control the concentrations of heavy metals in natural waters, their chemical reactivity and affinity sequence to the binding agents, their bioavailability, their ultimate fate, we need to know the form of occurrence of the metal. Analytically, however, one encounters difficulties in identifying unequivocally the various solute species and in distinguishing between dissolved and particulate concentrations. The ion selective electrode (ISE), if it were sufficiently sensitive, would permit the measurement of the free metal ion activity. Otherwise, no single simple method permits unequivocal identification of a species. Although voltammetry, especially differential pulse polarography (DPP) or anodic stripping voltammetry (ASV), is an extremely sensitive technique, one must be aware that it measures the electrochemically labile, i.e. the electrochemically available, metal ion concentration which in the case of $\mathrm{Cu}(\mathrm{II})$, for example, includes the carbonate and glycine complexes. At low $\mathrm{pH}$, the ASV technique gives values that may be representative of total soluble metal ion concentrations.

In assessing metal ion speciation, much attention is paid to the influence of soluble complex formers (e.g., fulvic or humic acids) or regulating the concentration of free metal ions. But particle surfaces rival with solute complex formers in tying up metal ions. Actually, particles are usually more important than soluble complex formers in regulating the concentrations of metal ions. In fresh waters, more than $95 \%$ of the heavy metals that are transported from land to sea occur in the form of particulate matter (Martin \& Meybeck, 1979).

Because there is usually no direct way to determine the actual metal species present, it becomes highly desirable to characterize in a given natural water sample the metal ion and its coordinative environment (particles and soluble complex formers) as well as possible, in order to derive some evidence on the plausible form of occurrence. Often, one determines total 'soluble' metal ion concentration in filtered and subsequently acidified samples. One then uses equilibrium calculations to estimate the free metal ion concentration that might have been present at the original $\mathrm{pH}$ of the water. Similarly, many workers titrate natural waters directly with trace metals by voltammetric detection methods to determine the so-called complexing capacity of the water. This capacity includes complexation by soluble complex formers (humic and fulvic acids) and by particle surfaces (oxides and organic and organical- 
ly coated particles) (Sigg et al., 1984; Gonçalves et al., 1985). Because of the very low metal ion concentrations in natural waters $\left(<<10^{-6} \mathrm{M}\right)$, the lack of sufficiently selective analytic sensors, and the complicated features in the interaction of the organic material with metal ions, ihere are many limitations involved in this approach (Varney et al., 1984; Buffle et al., 1984).

During recent years the interaction between heavy metals with dispersed solid surfaces and dissolved ligands has received much attention. Progress in methodology and physical chemical interpretation has been reviewed (Kramer \& Duinker, 1984; Davis \& Hayes, 1986; Stumm, 1987).

\section{Motivation}

Despite much progress in basic studies and theoretical interpretation, there is still a discrepancy between conceptual studies in the laboratory where variables are well defined or kept under control and investigations in real natural samples. In natural samples the concentrations of the reactants and/or of the metals are orders of magnitude lower than in laboratory model systems. A water- or soil scientist may need to interpret or 'diagnose' the properties of heavy metals in a real natural water, sediment-water, or soil-water sample that is characterized by a diversity of surfaces and dissolved concentrations smaller than $10^{-6} \mathrm{M}$. In such a natural sample one cannot have sufficiently sensitive measurements that are also unequivocal (with regard to speciation) (Varney et al., 1984). 'Recipes' - in some countries they are even standardized - lead the 'practitioner' to membrane-filter or centrifuge the sample and to determine the so-called complexing capacity after addition of a $\mathrm{pH}$ buffer ( $\mathrm{pH} 4.5-6)$ (titration of the sample with metal ions). Filtration and centrifugation introduce most serious errors (Sigg et al., 1984; Gonçalves et al., 1985, 1987) and the information gained from complexing capacity, especially if carried out at a $\mathrm{pH}$ much lower than that of the sample, is difficult to interpret.

We would like to suggest that the acidimetric titration of natural samples - ideally recording free metal ion concentration as a function of $\mathrm{pH}-$ is a relatively simple diagnostic tool to characterize the concentration of metal ions in natural waters and their coordinative environment and to assess how the system under consideration responds to the variation of $\mathrm{pH}$. The procedure corresponds to the classic procedure used in coordination chemistry to evaluate extent and stability of complex formation. Such a titration permits to assess the stability of the (surface and solute) complexes formed. The method is limited, however, by the lack of a sufficiently sensitive detector (specific sensor for the free metal ion activity, $\left[\mathrm{Me}^{2+}\right]$ ).

Voltammetric methods, especially anodic stripping voltammetry (ASV), have high sensitivity and are easy to use, but they are not sufficiently specific. As has been shown by many authors (see for example Buffle et al., 1984), ASV not only measures free metal ion concentration but also responds to complexes which are sufficiently labile to dissociate during the time scale of the measurement. The response may also be affected by interferences associated with the adsorption of organic matter on the electrode surface. As shown by Varney et al. (1984) and by others, the more sensitive voltammetric technique (ASV or differential pulse anodic stripping voltammetry (DPASV) reflect more labile $\mathrm{Cu}$ complexes than the less 
sensitive (shortest time scale) differential pulse polarography (DPP) technique. There is a trade-off between specificity and sensitivity.

We try to illustrate the principles of the acidimetric titration with the help of two model surface systems $\left(\mathrm{SiO}_{2}\right.$ and $\left.\mathrm{Fe}_{2} \mathrm{O}_{3}\right)$ and of humic acid in presence of heavy metal ions.

\section{Experimental}

Iron(III) colloidal stock solution was prepared in the same manner as reported by Florence (1982). $12.00 \mathrm{~g}$ of iron nitrate hexahydrate was dissolved in $50 \mathrm{ml}$ doubledistilled water, then $5 \mathrm{~g}$ of sodium hydrogen carbonate was added slowly with stirring over 30 minutes. The solution was left to stand for 24 hours and filtered through a $0.2-\mu \mathrm{m}$ filter. $1.0 \mathrm{ml}$ of filtrate was diluted into $100-\mathrm{ml}$ flasks. The iron concentration was determined by flame atomic absorption. This stock solution contained 81.5 $\mathrm{mg} \mathrm{dm}^{-3}$ of Fe. Its molecular weight is more than 500000 as determined by G-200 gel filtration.

$\mathrm{SiO}_{2}$ (Aerosil 380 from Degussa, Germany) particle suspension was prepared by washing the solid with $0.3 \mathrm{M} \mathrm{HCl}$ for several times and subsequently suspending it in double-distilled water. The particle concentration is determined by drying $2 \mathrm{ml}$ suspension at $95{ }^{\circ} \mathrm{C}$ overnight, $\mathrm{SiO}_{2}$ stock solutions of $15 \mathrm{~g} \mathrm{dm}^{-3}$ were obtained. Humic acid (type LL) was obtained by first leaching sediment samples from a lake with $1 \% \mathrm{NaOH}$ over several days; then the supernatant is filtered through a 0.45 $\mu \mathrm{m}$ filter and acidified to precipitate the humic acid. The humic acid obtained is purified twice by this repeating dissolution-precipitation procedure and finally by washing it with $0.01 \mathrm{~N} \mathrm{HNO}_{3}$ several times. The molecular weight distribution was determined by the gel filtration; the largest fraction of humic acid has a molecular weight of ca. 2000 .

\section{Results}

Case studies with $\mathrm{SiO}_{2}$ and $\mathrm{Fe}(\mathrm{OH})_{3}$ particles

Dispersions of $\mathrm{SiO}_{2}$ and $\mathrm{Fe}(\mathrm{OH})_{3}$ respectively were titrated acidimetrically or alkalimetrically in the presence of trace concentrations of $\mathrm{Pb}(\mathrm{II}), \mathrm{Cu}(\mathrm{II})$ and $\mathrm{Cd}(\mathrm{II})$ by voltammetric detection (DPP) to estimate the free metal ion concentration. The extent of surface binding (adsorption, or the distribution coefficient between particles and solution) on the hydrous oxide surface $(\equiv \mathrm{M}-\mathrm{OH})$ as a function of $\mathrm{pH}$ and other solution variables can be predicted with the help of surface complex formation constants which may be defined.

$$
\begin{array}{ll}
\equiv \mathrm{M}-\mathrm{OH}+\mathrm{Me}^{2+} \leftrightarrows \equiv \mathrm{M}-\mathrm{OMe}^{+}+\mathrm{H}^{+} & * \beta_{1}^{\mathrm{s}} \\
2 \equiv \mathrm{M}-\mathrm{OH}+\mathrm{Me}^{2+} \leftrightarrows(\equiv \mathrm{MO})_{2} \mathrm{ME}+2 \mathrm{H}^{+} & * \beta_{2}^{\mathrm{s}}
\end{array}
$$

The degree of surface protonation depends on the acid-base equilibria: 


$$
\begin{array}{ll}
\equiv \mathrm{M}-\mathrm{OH}_{2}{ }^{+} \leftrightarrows \equiv \mathrm{M}-\mathrm{OH}+\mathrm{H}^{+} & \mathrm{K}_{\mathrm{a} 1}^{\mathrm{s}} \\
\equiv \mathrm{M}-\mathrm{OH} \leftrightarrows \equiv \mathrm{M}-\mathrm{O}^{-}+\mathrm{H}^{+} & \mathrm{K}_{\mathrm{a} 2}^{\mathrm{s}}
\end{array}
$$

The experimental results can be plotted as an adsorption isotherm in various ways. In Fig. 1, the data are given as the fraction of metal ion adsorbed (bound) $\left(\left[\mathrm{Me}_{\text {bound }}\right] /\right.$ $\left[\mathrm{Me}_{\mathrm{T}}\right]$ as a function of $\mathrm{pH}$. Fig. 2 gives the same adsorption isotherm for $\mathrm{Fe}(\mathrm{OH})_{3}$. The ratio $\left[\mathrm{Me}_{\text {bound }}\right] /\left[\mathrm{Me}_{\mathrm{T}}\right]$ is given by $\left(\mathrm{i}_{\mathrm{T}}-\mathrm{i}_{\mathrm{p}}\right) / \mathrm{i}_{\mathrm{T}}$ where $\mathrm{i}_{\mathrm{T}}$ is the total current measured for $\left[\mathrm{Me}_{\mathrm{T}}\right]$ at low $\mathrm{pH}$ in the absence of surfaces and ligands $\left(\left[\mathrm{Me}_{\mathrm{T}}\right] / \mathrm{i}_{\mathrm{T}}=\mathrm{k}\right)$ and $i_{p}$ is the peak current measured in the presence of surfaces. $i_{p}$ relates linearily to

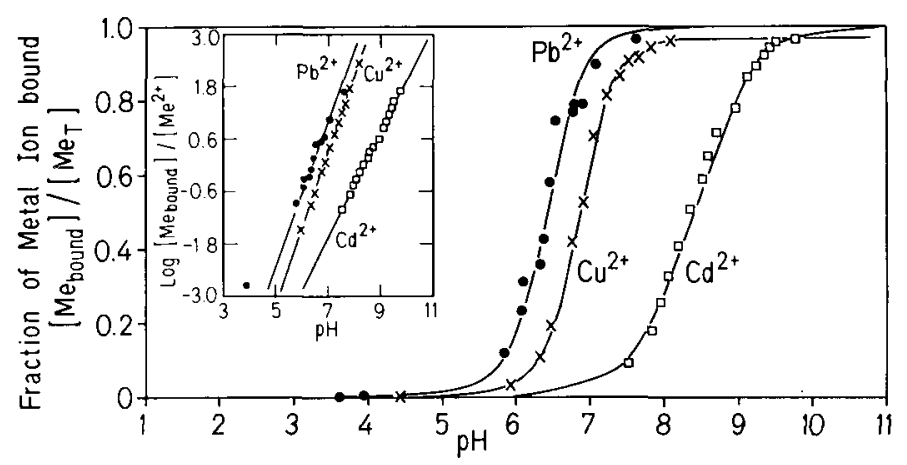

Fig. 1. Binding of metal ions by amorphous silica, $300 \mathrm{mg} \mathrm{SiO} 2 \mathrm{dm}^{-3},\left[\mathrm{Me}_{\mathrm{T}} \approx 10^{-5} \mathrm{M}\right]$. The fraction of metal ion bound was calculated from peak currents measured with differential pulse polarography, DPP: $\left(\mathrm{i}_{\mathrm{T}}-\mathrm{i}_{\mathrm{p}}\right) / \mathrm{i}_{\mathrm{T}} \approx\left[\mathrm{Me}_{\text {bound }}\right] /\left[\mathrm{Me}_{\mathrm{T}}\right]$ :

In the inset, linearized plots of $\log \left[\mathrm{Me}_{\text {bound }}\right] /\left[\mathrm{Me}^{2+}\right]$ are plotted as a function of $\mathrm{pH}$. The slopes $\mathrm{n}=$ $-\mathrm{d}\left[\mathrm{Me}^{2+}\right] / \mathrm{d}\left[\mathrm{H}^{+}\right]$are $1.72,1.77$ and 1.12 for $\mathrm{Pb}^{2+}, \mathrm{Cu}^{2+}$ and $\mathrm{Cd}^{2+}$ respectively. The lines drawn have been calculated with the contants given in Table 1.

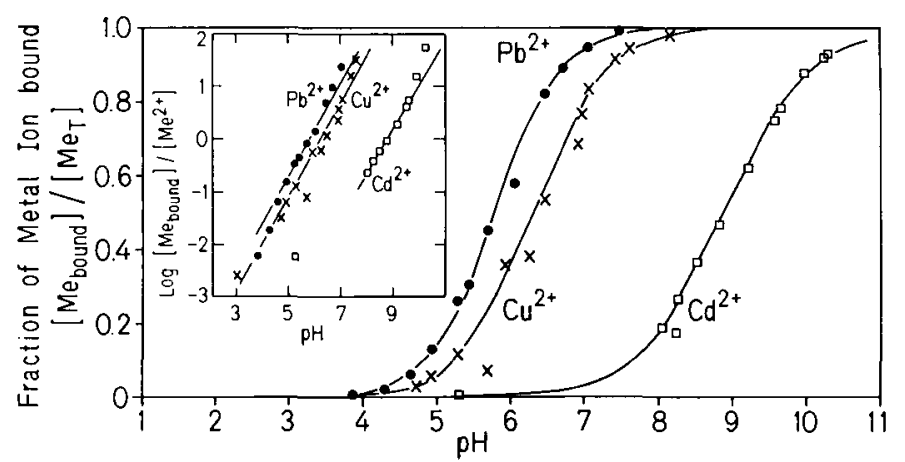

Fig. 2. Binding of metal ions by Fe(III) colloid $\left(60 \mathrm{mg} \mathrm{Fe}(\mathrm{OH})_{3} \mathrm{dm}^{-3}\left[\mathrm{Me}_{\mathrm{T}}\right) \approx 2 \times 10^{-5} \mathrm{M}\right)$. The lines drawn have been calculated with the constants given in Table 1 . The slopes, $\mathrm{n}$, in the inset are ca. 1.0. The fraction of metal ion bound has been obtained from DPP measurements: $\left(\mathrm{i}_{\mathrm{T}}-\mathrm{P}_{\mathrm{p}}\right) / \mathrm{i}_{\mathrm{T}}$. 
Table 1. Surface complex formation constants for the interaction of $\mathrm{Pb}^{2+}, \mathrm{Cu}^{2+}$ and $\mathrm{Cd}^{2+}$ with colloidal $\mathrm{Fe}(\mathrm{OH})_{3}$ and amorphous $\mathrm{SiO}_{2}(\mathrm{I}=0.01 \mathrm{M})$.

\begin{tabular}{|c|c|c|c|c|c|}
\hline & \multirow{2}{*}{$\begin{array}{l}\mathrm{Cd}^{2+} \\
\log * \beta_{1}^{s}\end{array}$} & \multicolumn{2}{|l|}{$\mathrm{Pb}^{2+}$} & \multicolumn{2}{|l|}{$\mathrm{Cu}^{2+}$} \\
\hline & & $\log * \beta_{1}$ & $\log * \beta_{2}$ & $\log \beta_{1}$ & $\log \beta_{2}$ \\
\hline $\mathrm{Fe}(\mathrm{OH})_{3}(\mathrm{~s})$ & -4 & -1.6 & - & -1.7 & - \\
\hline $\mathrm{SiO}_{2}$ amorphous (s) & -5.1 & -3.8 & -8.2 & -4.3 & -10.4 \\
\hline
\end{tabular}

$\left[\mathrm{Me}_{\text {labile }}\right],\left(\left[\mathrm{Me}_{\text {labile }}\right] / \mathrm{i}_{\mathrm{p}}=\mathrm{k}\right)$, where $\left[\mathrm{Me}_{\text {labile }}\right]$ (in the absence of organic complex formers) in these experiments consists of free metal ions, $\left[\mathrm{Me}^{2+}\right]$, and hydroxo metal complexes. The concentration of free metal ion concentration is related to the labile metal ion concentration by $\left[\mathrm{Me}^{2+}\right] /\left[\mathrm{Me}_{\text {labile }}\right]=\alpha_{\mathrm{H}}$.

The data can be readily interpreted in terms of simplified surface complex formation equilibria. The evaluation can be made conveniently by combining Eqs. 1 and 2 to

$$
\begin{aligned}
& \mathrm{n} \equiv \mathrm{MOH}+\mathrm{Me}^{2+} \leftrightarrows(\equiv \mathrm{MO})_{\mathrm{n}} \mathrm{Me}+\mathrm{n} \mathrm{H}^{+} \\
& * \beta_{\mathrm{n}}=\frac{\left\{(\equiv \mathrm{MO})_{\mathrm{n}} \mathrm{Me}\right\}\left[\mathrm{H}^{+}\right]^{\mathrm{n}}}{\left[\mathrm{ME}^{2+}\right]\{\equiv \mathrm{MOH}\}^{\mathrm{n}}}
\end{aligned}
$$

The $n$ value is evaluated from a plot of $\log \left\{(\equiv \mathrm{MO})_{\mathrm{n}} \mathrm{Me}\right\} /\left[\mathrm{Me}^{2+}\right]$ or $\log \left[\mathrm{Me}_{\text {bound }}\right] /$ $\left[\mathrm{Me}^{2+}\right]$ vs. $\mathrm{pH}$. Under the condition that the concentration of surface groups, $\{\equiv \mathrm{MOH}\}$, is in large excess with respect to the total metal concentration, this plot is a straight line with $\mathrm{pH}$ slope smaller than 2 but larger than one. $\left[\mathrm{Me}^{2+}\right]$ has been calculated from the peak current $\left(\left[\mathrm{Me}^{2+}\right]=\mathrm{i}_{\mathrm{p}} \cdot \mathrm{k} \alpha_{\mathrm{H}}\right)$. One may note that we treat - as a first approximation - the surface as if it were uncharged; i.e., the surface potential is assumed to be zero. A more exact treatment to derive the $\mathrm{pH}$ dependence of metal binding to surfaces was given by Hohl \& Stumm (1976). The data for complex formation of metals with $\mathrm{SiO}_{2}$ (Table 1) are similar to those obtained by Schindler et al. (1976) for I = $1 \mathrm{M}$.

Case studies on the interaction of heavy metals with natural humic acids

The interaction of humic acids (or fulvic acids) with metal ions is complicated by the fact that the humic acids (i) are polyfunctional (mixture of ligands with different functional groups), (ii) are polyelectrolytic; and (iii) may be present in dissolved or colloidal (suspended) form. The interaction with humic acid as a quasiparticle (Sposito, 1985) can be formulated in the most general form:

$$
\begin{aligned}
& \text { a SH} H_{n}(\text { aq. or s })+\mathrm{pMe}^{2+}+\mathrm{qL}^{l_{-}}+\mathrm{xH}^{+}+\mathrm{yOH}^{-} \\
& \leftrightarrows \mathrm{S}_{\mathrm{a}} \mathrm{Me}_{\mathrm{p}}(\mathrm{OH})_{\mathrm{x}} \mathrm{L}_{\mathrm{q}}^{\delta}(\mathrm{aq} \text {. or } \mathrm{s})+\mathrm{b} \mathrm{H}^{+}
\end{aligned}
$$

where $\delta=2 \mathrm{p}+\mathrm{x}-\mathrm{y}-\mathrm{lq}$, and $\mathrm{b}=$ na. Eq. 6 can often be simplified to 


$$
\begin{aligned}
& \mathrm{a} \mathrm{LH}^{-}+\mathrm{Me}^{2+}=\mathrm{MeL}_{\mathrm{a}}^{2(1-\mathrm{a})}+\mathrm{aH}^{+} \\
& \mathrm{K}_{\mathrm{H}}=\frac{\left\{\mathrm{MeL}_{\mathrm{a}}\right\}\left[\mathrm{H}^{+}\right]^{\mathrm{a}}}{\left\{\mathrm{LH}^{-}\right\}^{\mathrm{a}}\left[\mathrm{Me}^{2+}\right]}
\end{aligned}
$$

for simplicity, the charge of $\mathrm{MeL}_{\mathrm{a}}$ in Eq. $7 \mathrm{~b}$ is omitted.

$\mathrm{LH}^{-}$is used in Eq. 7a to represent the fact that much (most) of the humic acid in natural waters is present as anionic species. Eq. 7 is a simple semi-empirical expression for the average effect of metal ion binding to a polyfunctional, polyelectrolytic ligand mixture. $\mathrm{K}_{\mathrm{H}}$ values are data fitting quotients, valid for certain conditions, e.g. ionic strength and ranges of $\left[\mathrm{L}_{\mathrm{T}}\right] /\left[\mathrm{Me}_{\mathrm{T}}\right]$ ratios. The quotients may be improved by making corrections for charge.

For every metal ion Me interacting, Eq. 7 can be rewritten:

$$
\log \frac{\left\{\mathrm{Me}_{\mathrm{i}}-\mathrm{L}_{\mathrm{a}}\right\}}{\left[\mathrm{Me}_{\mathrm{i}}^{2+}\right]}=\log \mathrm{K}_{\mathrm{H}}+\mathrm{a}_{\mathrm{i}} \log \frac{\left\{\mathrm{LH}^{-}\right\}}{\left[\mathrm{H}^{+}\right]}
$$

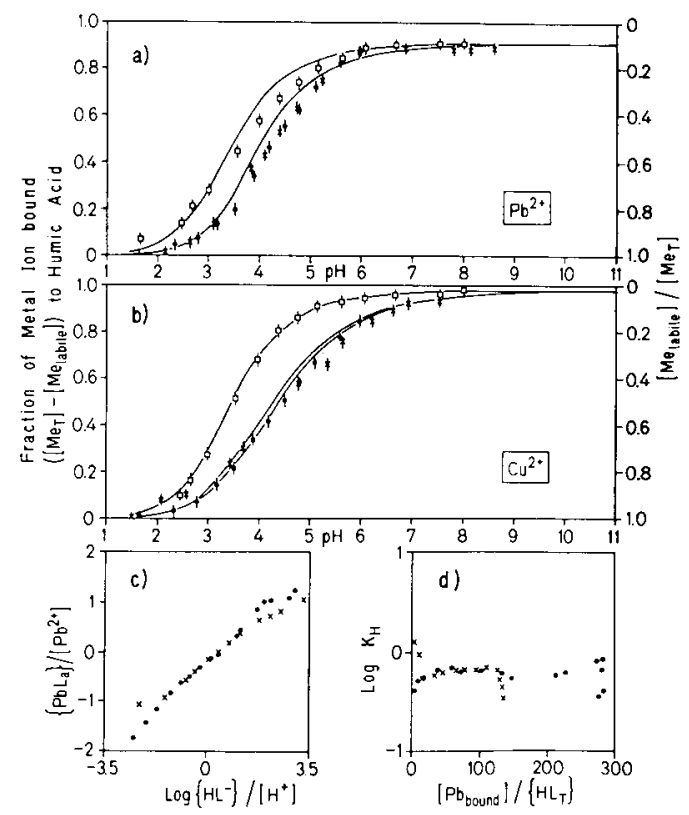

Fig. 3. Interaction of $\mathrm{Pb}(\mathrm{II})$ and $\mathrm{Cu}$ (II) with humic acid (type $\mathrm{LL}$ ) for various concentrations:

$\mathrm{HA}=21.34 \mathrm{mg} \mathrm{C} \mathrm{dm}-3:[\mathrm{Me}]_{\mathrm{T}}=1 \times 10^{-5} \mathrm{M}$

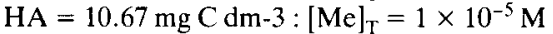

$\mathrm{HA}=10.67 \mathrm{mg} \mathrm{C} \mathrm{dm}-3:[\mathrm{Me}]_{\mathrm{T}}=2 \times 10^{-5} \mathrm{M}$

The fraction of metal ion bound, or more precisely the fracion of non-labile metal ion, $\left(i_{T}-i_{p}\right) / i_{T}$, as measured voltammetrically by DPP is plotted as a function of $\mathrm{pH}$.

Fig. $3 \mathrm{c}$ gives a plot of the data of Fig. $3 \mathrm{a}$ in the form of Eq. 8 to evaluate an empirical equilibrium quotient $\mathrm{K}_{\mathrm{H}}$ (Eq. $7 \mathrm{~b}$ ).

Log $K_{H}$ is plotted in Fig. $3 \mathrm{~d}$ as a function of the metal to ligand ratio. 


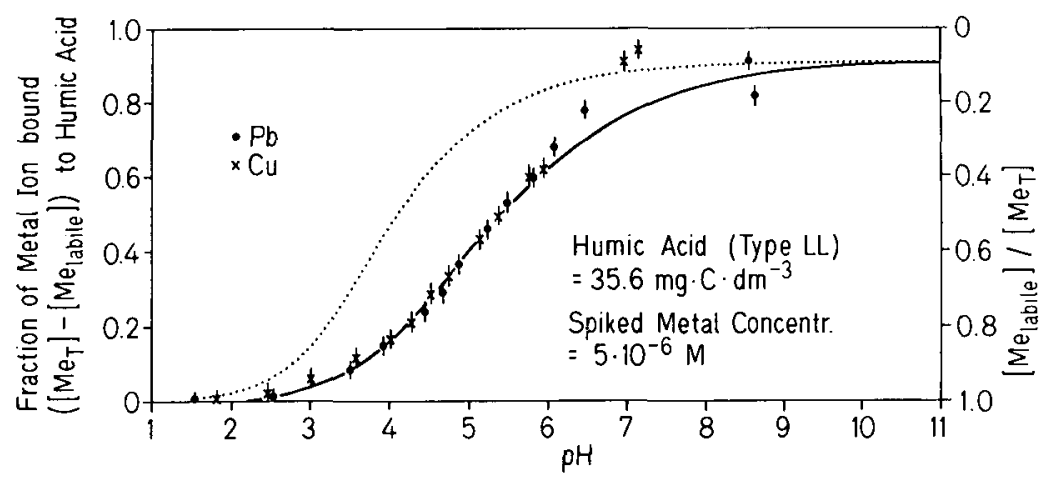

Fig. 4. $\mathrm{pH}$ dependence of metal ion binding to humic acid as measured voltammetrically by DPP in presence of $2 \times 10^{-3} \mathrm{M} \mathrm{Ca}^{2+}$ and $4 \times 10^{-4} \mathrm{M} \mathrm{Mg}^{2+}$. The dotted line corresponds to that calculated if no other metals $\left(\mathrm{Ca}^{2+}, \mathrm{Mg}^{2+}\right)$ were present. The shift toward higher $\mathrm{pH}$ values is caused by the competition of earth alkali ions.

The left hand side of Eq. 8 is assessed from voltammetric information. As a first approximation it is given by $\log \left(\mathrm{i}_{\mathrm{T}}-\mathrm{i}_{\mathrm{p}}\right) /\left(\mathrm{i}_{\mathrm{p}} \cdot \alpha_{\mathrm{H}}\right)$. A plot according to Eq. 8 is given in Fig. $3 \mathrm{c}$ for $\mathrm{Pb}(\mathrm{II})$ on humic acid (type $\mathrm{LL}$ ) $[\mathrm{Pb}$ bound $] /\left\{\mathrm{HL}_{\mathrm{T}}\right\}, \mathrm{K}_{\mathrm{H}}$ values are plotted in Fig. 3d.

Data obtained for $\mathrm{Pb}(\mathrm{II})$ and $\mathrm{Cu}(\mathrm{II})$ interaction with various concentrations of humic acid are given in Figs. 3 and 4. In these figures, ordinate vaules have been computed from $\left(i_{T}-i_{p}\right) / i_{T}$ ratios that, in a first approximation, correspond to the fraction of metal ion bound to humic acid to total metal ion present, $\left[\mathrm{Me}_{\text {bound }}\right] /$ $\left[\mathrm{Me}_{\mathrm{T}}\right]$. As noticed in Fig. 3, a constant fraction of $\left(\mathrm{i}_{\mathrm{T}}-\mathrm{i}_{\mathrm{p}}\right) / \mathrm{i}_{\mathrm{T}}$ remains at high $\mathrm{pH}$ values. This may be due to some dissociation of the humic acid complex; i.e. some of the labile current measured is caused by metal ion dissociating from the humic acid complex during the measurement.

Fig. 4 illustrates the tendency to complex formation of $\mathrm{Pb}(\mathrm{II})$ and $\mathrm{Cu}(\mathrm{II})$ with humic acids under conditions more typically encountered in real systems where an excess of $\mathrm{Ca}^{2+}\left(2 \times 10^{-3} \mathrm{M}\right)$ and $\mathrm{Mg}^{2+}\left(4 \times 10^{-4} \mathrm{M}\right)$ is present. It is interesting to note that the extent of metal complexing extends over many $\mathrm{pH}$ units. In other words, humic acids provide metal ion buffering over a broad $\mathrm{pH}$ range.

\section{Total site concentrations}

For an evaluation of the equilibrium quotients $\mathrm{K}_{\mathrm{H}}$ and for a fully generalizable characterization of the $\mathrm{pH}$-dependent interaction we need to determine the maximum protolyzable site concentration $\mathrm{CC}(\mathrm{H})$ (total capacity to bind protons) and the metal complexing capacity $\mathrm{CC}(\mathrm{M})$ of the humic acids. $\mathrm{CC}(\mathrm{H})$ is obtained most readily from alkalimetric titration (Fig. 5). Plotting the data in the form of the Henderson-Hasselbach equation, an intrinsic acidity constant can be determined by extrapolating to zero charge.

The complexing capacity for metal ions $\mathrm{CC}(\mathrm{Me})$ was determined by titrating the corresponding metal ions at constant $\mathrm{pH}$ values with ligands (humic acid, previous- 


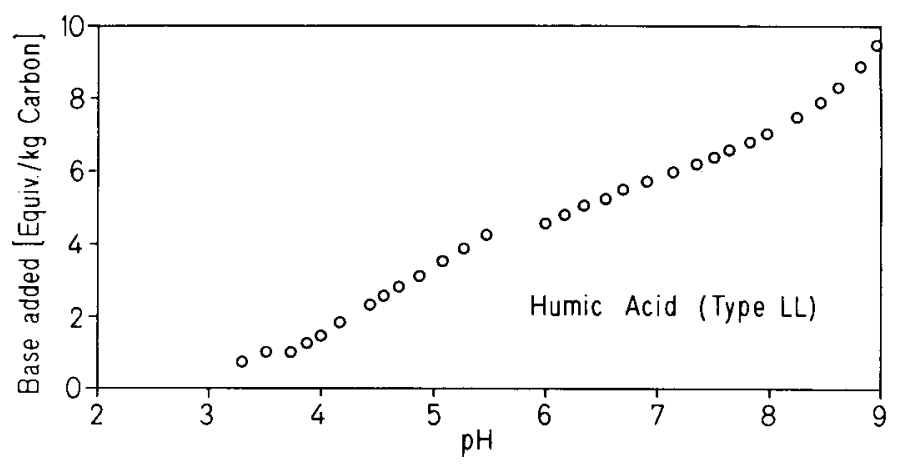

Fig. 5. Alkalimetric titration curve of humic acid $\left(15.7 \mathrm{mg} \mathrm{C} / \mathrm{dm}^{3}\right)$.

Table 2. Constants for the interaction of $\mathrm{Cu}(\mathrm{II}), \mathrm{Pb}(\mathrm{II})$ and $\mathrm{Cd}(\mathrm{II})$ with humic acid (type $\mathrm{LL}$ ). Capacity for $\mathrm{H}^{+}$ions to $\mathrm{pH} 7$ : $\mathrm{CC}(\mathrm{H})=5.7 \mathrm{~mol}$ per $\mathrm{kg} \mathrm{C}$.

\begin{tabular}{llll}
\hline & $\begin{array}{l}\mathrm{CC}(\mathrm{Me})^{*} \\
(\mathrm{~mol} / \mathrm{kgC})\end{array}$ & $\mathrm{K}_{\mathrm{H}}{ }^{* *}$ & $\mathrm{a}^{* *}$ \\
$\mathrm{Cu}^{2+}$ & 2.5 & 1.2 & 0.41 \\
$\mathrm{~Pb}^{2+}$ & 2.6 & 2.1 & 0.47 \\
$\mathrm{Cd}^{2+}$ & 1.2 & 0.14 & 0.3 \\
\hline
\end{tabular}

* This has been determined for $\mathrm{Pb}(\mathrm{II})$ and $\mathrm{Cu}(\mathrm{II})$ at $\mathrm{pH} 6.5$ and for $\mathrm{Cd}(\mathrm{II})$ at $\mathrm{pH} 8.5$.

** See Eq. $7 \mathrm{~b}$. The data were obtained for humic acids of the concentration $10.7 \mathrm{mg} \mathrm{C} \mathrm{dm}^{-3}$ and total metal concentrations of $10^{-5} \mathrm{M}$.

ly extracted from the water). Plotting the $\left[\mathrm{Me}_{\text {bound }}\right]$, as measured by $\left(\mathrm{i}_{\mathrm{t}}-\mathrm{i}_{\mathrm{p}}\right) \cdot \mathrm{k}$ vs. the humic acid added ( $\mathrm{mg}$ carbon added per $\mathrm{dm}^{3}$ of solution), the slope gives $\mathrm{CC}(\mathrm{Me})$. Table 2 summarizes the data obtained by an iterative computer program.

\section{References}

Bolt, G. H. \& W. H. van Riemsdijk, 1987. Surface chemical processes in soil. In: W. Stumm (Ed.), Aquatic surface chemistry, p. 127-164. Wiley-Interscience, New York.

Buffle, J., A. Tessier \& W. Haerdi, 1984. Interpretation of trace metal complexation by aquatic organic matter. In: C. J. M. Kramer \& J. C. Duinker (Eds.), Complexation of trace metals in natural waters, p. 301-306. Martinus Nijhoff/Dr. W. Junk Publishers, The Hague.

Cabaniss, S. E., M. S. Shumann \& B. J. Collins, 1984. Metal-organic binding: a comparison of models. In: C. J. M. Kramer \& C. J. Duinker (Eds.), Complexation of trace metals in natural waters, p. 165179. Martinus Nijhoff/Dr. W. Junk Publishers, The Hague.

Davis, J. A. \& K. F. Hayes (Eds.), 1986. Geochemical processes at mineral surfaces. American Chemical Society, Washington, DC, USA, $683 \mathrm{pp}$.

Gonçalves, M. S., L. Sigg \& W. Stumm, 1985. Voltammetric methods for distinguishing between dissolved and particulate metal ion concentrations in presence of hydrous oxides. Environmental Science and Technology 19: 141-146. 


\section{ZI-JIAN WANG AND WERNER STUMM}

Gonçalves, M. S., L. Sigg, M. Reutlinger \& W. Stumm, 1987. Metal ion binding by biological surfaces: voltammetric assessment in presence of bacteria. The Science of the Total Environment 60: 105-119.

Hohl, H. \& W. Stumm, 1976. Interaction of $\mathrm{Pb}^{2+}$ with hydrous $\mathrm{Al}_{2} \mathrm{O}_{3}$. Journal of Colloid and Interface Science 55: 281-288.

Kramer, C. J. M. \& J. C. Duinker (Eds.), 1984. Complexation of trace metals in natural waters. Martinus Nijhoff/Dr. W. Junk Publishers, The Hague, 448 pp.

Martin, J. M. \& M. Meybeck, 1979.Elemental mass-balance of material carried by world major rivers. Marine Chemistry 7: 173-206.

Perdue, E. M. \& C. R. Lytle, 1983. A critical examination of metal-ligand complexation models: application to defined multiligand mixtures. In: R. F. Christman \& E. T. Gjessing (Eds.), Aquatic and terrestrial humic materials, p. 295-313. Ann Arbor Science Publishers, Ann Arbor, MI, USA.

Schindler, P. W., B. Fuerst, R. Dick \& P. Wolf, 1976. Ligand properties of surface silanol groups. I. Surface complex formation with $\mathrm{Fe}^{3-}, \mathrm{Cu}^{2-}, \mathrm{Cd}^{2-}$, and $\mathrm{Pb}^{2-}$. Journal of Colloid and Interface Science 55: $469-475$.

Schindler, P. W. \& W. Stumm, 1987. The surface chemistry of oxides, hydroxides, and oxide minerals. In: W. Stumm (Ed.), Aquatic surface chemistry, p. 83-110. Wiley-Interscience, New York.

Sigg, L., W. Stumm \& B. Zinder, 1984. Chemical processes at the particle/water interface: implications concerning the form of occurrence of solute and adsorbed species. In: C. J. M. Kramer \& J. C. Duinker (Eds.), Complexation of trace metals in natural waters, p. 251-266. Martinus Nijhoff/Dr. W. Junk Publishers, The Hague.

Sposito, G., 1986. Sorption of trace metals by humic materials in soils and natural waters. CRC Critical Reviews in Environmental Control 16: 193-229.

Stumm, W. (Ed.), 1987. Aquatic surface chemistry: Chemical processes at the particle/water interface. Wiley-Interscience, New York, $520 \mathrm{pp}$.

Stumm, W., H. Hohl \& F. Dalang, 1976. Interaction of metal ions with hydrous oxide surface. Croatica Chemica Acta 48: 491-504.

Varney, M. S., D. R. Turner, M. Whitfield \& R. F. C. Mantoura, 1984. The use of electrochemical techniques to monitor complexation capacity titrations in natural waters. In: C. J. M. Kramer \& J. C. Duinker (Eds.), Complexation of trace metals in natural waters, p. 33-46. Martinus Nijhoff/Dr. W. Junk Publishers, The Hague. 